\title{
Determining the In-Pipe Anaerobic Processing Distance before Draining to Oxidation Pond of Municipal Wastewater Treatment
}

\author{
Satreethai Poommai, Kasem Chunkao, Narauchid Dumpin, Saowalak Boonmang, and Chatri Nimpee, \\ Member, IACSIT
}

\begin{abstract}
H. M. The King's initiative Laem Phak Bia environmental research and development (LERD) project has been selected Laem Phak Bia sub-district, Ban Laem district, Petchaburi province which is about $18.5 \mathrm{~km}$ away from points sources at Petchaburi municipal. Transferring community wastewater was really needed to take HPDE pipe because of high pressure requirement for $50-\mathrm{cm}$ head between Klongyang pumping station to the project site and also unpleasant smell in case of using open channel sewer system. The original point sources are far away about $5 \mathrm{~km}$ to $8 \mathrm{~km}$ to in-town collection pond which is localized at fresh-food markets, households, shopping center, dessert factories, Thai rice noodle factories, and government offices in which they produce wastewater approximately $7,000 \mathrm{~m} 3 / \mathrm{d}$. The pumping capacity was estimated 3,000 to $3,600 \mathrm{~m} 3 / \mathrm{d}$ through $18.5-\mathrm{km}$ HPDE pipe to the LERD's project site without any interruption. The research results found that the Royal LERD wastewater treatment system to decrease the high content of BOD down to under standard value after overflowing weir crest of the last pond (pond5). In addition, the anaerobic organic digestion processing distance was determined by graphical method with free hand curving that pointing out on 2,000 meters that moving from the start-up point at Klongyang collection pond through the 18.5km HPDE pipe tail. Only the values of BOD and anaerobes had evidently shown in variable patterns, but the others found more or less changeable patterns, i.e. COD, NH4, NO2, alkalinity, hardness, SS. TDS, EC, orthophosphate, total phosphate, temperature, aerobes, facultative bacteria, total coliform, fecal bacteria, and DO (0.000 to $0.003 \mathrm{mg} / \mathrm{L})$.
\end{abstract}

Index Terms-Anaerobic organic digestion, wastewater treatment, nature-by-nature.

\section{INTRODUCTION}

Thailand has been declared her self as producing food country to feed the population of the world, particularly rice, fruits, vegetables, chickens, pork, shrimps, and canned food as well as in-flight food of oversee airlines in which the food factories and canneries have to be established in order to cook canned food another foodstuff to supply in-the-country and exporting to oversee countries. Such food producing activities could not be ignored the wastewater fresh-food markets, canneries, and food industrial factories that

Manuscript received November 10, 2012; revised January 31, 2013.

Satreethai Poommai, Narauchid Dumpin, and Chatri Nimpee are with the Faculty of Environment, Kasetsart University, Bangkok, Thailand (e-mail: satreethai.p@ku.ac.th, ecncd@ku.ac.th).

Kasem Chunkao and Saowalak Boonmang are with the King's initiative Laem Phak Bia environmental research and development (LERD) project and the Faculty of Environment, Kasetsart University, Bangkok, Thailand (e:mail:ecksc@ku.ac.th). expanding to the product raw materials around the country, especially more densities in the central, the south, the east, and the upper north but less number in the northeast. Petchaburi province is one the area that locating between the central and the south which is abundance of marine animals in the Gulf of Thailand, irrigated rice fields, fruit plantations (pine apple, rose apple, sugar palm, coconut palm, lemon), vegetables (been, asparagus, peanut, soybean), and salt pan. It is no doubtful why Petchaburi province is composed of a lot of dessert factories, food industrial factories, and the best fresh-food markets for producing all kinds of foodstuff for consuming in-the-country and exporting. Consequently, high amount and organic contaminant wastewater from food industrial factories, canneries, fresh-food markets, dessert factories, as well as even households, community, and municipals have been disorderly settled every part of the province, particularly along the stream banks of Petchaburi river on which the stream pollution was obvious before the year of 1990. Since then, H.M. the King has valuably initiated the nature-by-nature process for wastewater treatment by employing the 5-consecutive oxidation ponds after transferring high organic concentrated wastewater from point sources inside Petchaburi municipal (fresh-food markets, households, overnight food centers, dessert factories, shopping center, schools, and government offices), through sewer systems (modifying by uplifting the tip of drained pipe flowing backwards to main sewer instead of draining into Petchaburi river), then pumping them to collect at Klongyang collection pond before pumping through the 18.5-km HPDE pipe, and finally to the sedimentation pond (the first pond of 5-consecutive oxidation ponds [1], [2]. It would be emphasized that the King's initiative nature-by-nature process for community wastewater treatment has been succeeded with obtaining the treated community wastewater under standard as set by the government. Nevertheless, the objectives of this study are aimed to obtain the anaerobic organic digestion processing distance to apply the results for prior working out the high BOD concentrated wastewater from point sources of food industrial factories, canneries, and others before draining into the oxidation ponds under the nature-by-nature process.

Due to high concentrated organic contaminant in wastewater from various points sources as above statement, only employing the oxidation ponds under nature-by-nature process [3] which is mainly biological process, cannot remove the organic and some inorganic contaminants down to the standard values. It is understood among wastewater managing scientists that the anaerobic process has to conduct 
until BOD below $200 \mathrm{mg} / \mathrm{L}$ before draining them into the consecutive ponds in order that decreasing the BOD effluent be low standard (20 mg/L) [4]. It is surprising that the anaerobic processing distance was not principally indicated in previous research not only in warmer climate of Thailand but also some other tropical countries. Therefore, this study is expectedly to find out the organic digestion processing distance in order to apply for decreasing the high content BOD of wastewater from canneries, food industrial factories, dessert factories, fresh-food markets, and food centers and others in Petchaburi province and another target areas around the country for supporting the application of the Royal community wastewater treatment technology under nature-by-nature process together with employing 5-consecutive oxidation ponds in all parts of the country.

Bacterial organic digestion is naturally identified in both an aerobic and anaerobic processes to convert the organic matters into inorganic materials plus gases and heat energy [5]-[8]. It is well understood that the solid product has received from aerobic process more than anaerobic process because of obtaining free oxygen from natural processes by plant photosynthesis, thermo-siphon, or thermo-osmosis processes [9]-[13], conversely the product of bad smell gases more from anaerobic than aerobic process due to the oxygen in part of organic compounds that being extracted by anaerobes and causing the occurrence of bad smell gases of hydrogen sulfide, ammonia, methane, and others [14]-[19]. However, the anaerobic bacteria is normally susceptible to free oxygen neither death nor inactive living. Also, the anaerobic process can survive in place without free oxygen as stated before in which the rate of bad smell gases are produced more or less depending on the quantity and quality of organic compound as the same as the mixing elements [20], [21]. In the real anaerobic process, the bacterial organic digestion processes are identified as the faster decreasing rate of organic matter because of its property as facultative condition which could be active no matter free oxygen or extracted oxygen from organic compounds [22]-[23]. Thus, in order that decreasing organic content should use for an anaerobic organic digestion processes before an aerobic organic digestion processes for completion of organic eradication in community wastewater treatment. In other words, an anaerobic process plays vital role in decreasing the high concentration of biological oxygen demand (BOD) in any wastewater before employing an aerobic organic digestion process for wastewater treatment in the 5-consecutive oxidation pond, especially wastewater from food industrial factories, canneries, and more organic waste contamination[24], [25].

\section{Methodology}

\section{A. Modification of Sewage System}

LERD [26] reported that Petchaburi municipal, like the another cities in Thailand, is located along both sides of river banks in order to take water serving day to day the people's lifestyles. Consequently, more than $80 \%$ of water using become to community wastewater which is drained through the sewage system and then flowing into the Petchaburi river that polluting stream water with very severeness of toxicity. For this reason, H.M. the King has initiated the Royal Laem Phak Bia environmental research and development (the Royal LERD) under nature-by-nature process for community wastewater treatment by oxidation ponds about $18.5 \mathrm{~km}$ from Petchaburi municipal far away to the east direction and on mud-beach mangrove forest, the edge of the Gulf of Thailand at Laem Phak Bia sub-district, Ban Laem district, Petchaburi province. In order to decrease organic matters in wastewater under standard, the sewage system was to modify instead of direct flow to the river but taking them to the collection pond before pumping to the 5-consecutive oxidation ponds at the project site as shown in Fig. 1.

The modified sewage system was taken by uplifting the culvert tails for making backward flow to main drained sewer before pumping to the collection pond. Then after, the 18.5-km HPDE pipes with 11 manholes were laid down along the irrigated-canal dikes of Royal Irrigation Department for transferring community wastewater from collection pond to the 5-consecutive oxidation ponds under an anaerobic organic digestion process (see Fig. 2). The Petchaburi municipal wastewater has been pumped approximately $3,600 \mathrm{~m}^{3} / \mathrm{d}$ of total $7,000 \mathrm{~m}^{3} / \mathrm{d}$ with $5.5-\mathrm{hr}$ traveling time from the collection pond to the sedimentation pond (pond1).

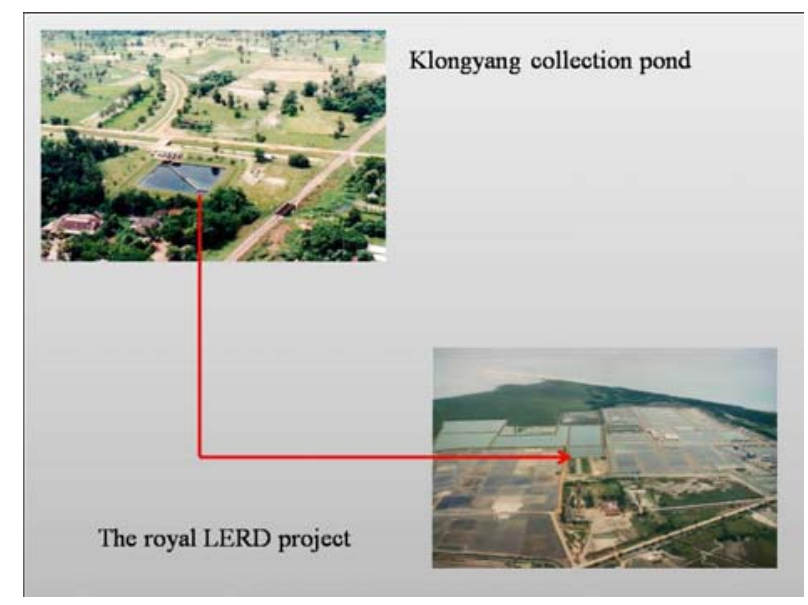

Fig. 1. Location of Petchaburi municipal and Klongyang collection pond as linked by the 18.5-km HPDE pipe to the Royal LERD project at Laem Phak Bia sub- district, Ban Laem district, Petchaburi province.

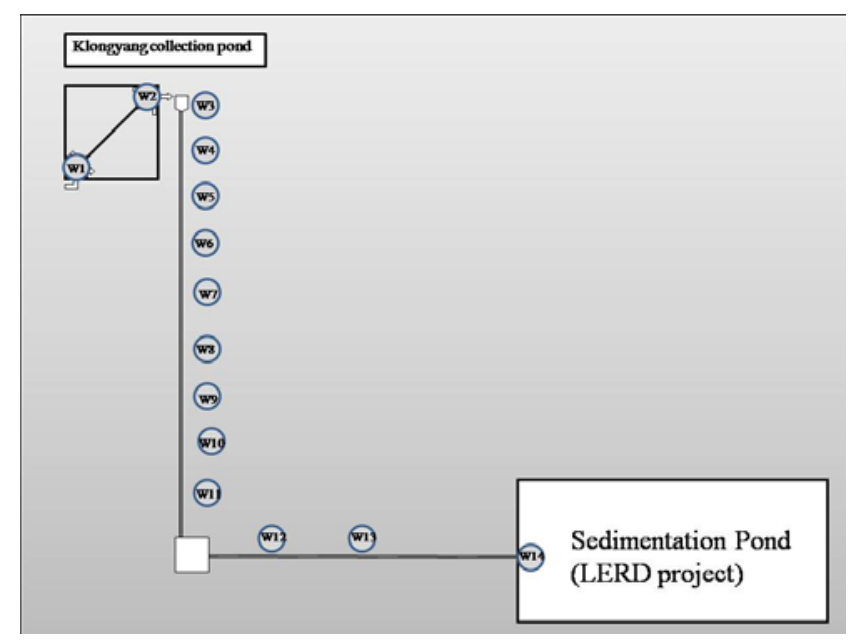

Fig. 2. Sketching the wastewater transferring from Klongyang collection pond through the 18.5-HPDE pipe with 11 manholes including the wastewater sampling points at $\mathrm{W} 1$ to $\mathrm{W} 14$. 


\section{B. Wastewater Sampling and Analysis}

Wastewater were taken 2 samples in collection pond (2 sub-ponds), 11 samples at 11 manholes of the $18.5-\mathrm{km}$ HPDE pipe (12 inches in diameter), and 1 sample at the 18.5-km pipe tail for analyzing water quality indexes of BOD, COD, $\mathrm{NH}_{4}, \mathrm{NO}_{2}, \mathrm{NO}_{3}$, alkalinity, hardness, SS, TDS, EC, temperature, orthophosphate, total coliform, fecal coliform, aerobes, anaerobes, and facultative bacteria in order to study on the influence of in-pipe anaerobic processes. The wastewater analysis will be based on [27] and the specific extraction may be applied from some articles, for examples [28].Results and Discussion.

The Royal LERD project has been set up for long-term research and development in improving environmental pollution in Thailand, particularly community wastewater treatment and garbage disposal which could be at a standstill. Intentionally, not only research and development but also its finding is disseminated to all levels of people in environmental education program getting the public collaboration for the pleasant environment of the country. Thus, the research results have been done by taking randomly representatives of the whole picture and will be presented in the following sections.

In field practicing, the wastewater treatment efficiency was randomly sampled during August to October 2010 for about 80-hour traveling time from the points sources at fresh-food markets and households through the drainage sewer system, passing Klongyang collection pond, then traveling through the $18.5-\mathrm{km}$ pipe before flowing to pond1 (sedimentation pond) and another 4-consecutive oxidation ponds that handing out the effluent to mangrove forest and to the mud beach, finally to seashore Belonging to the Gulf of Thailand as shown in Table I. It is seen that the Royal LERD community wastewater system has revealed high efficiency in which the values of BOD was very high concentration at the fresh-food markets together with households in BOD $546.6 \mathrm{mg} / \mathrm{L}$ and drastic decreasing at drainage culvert system of BOD $162.7 \mathrm{mg} / \mathrm{L}$, lowering down to $79.5 \mathrm{mg} / \mathrm{L}$, BOD 43.7 $\mathrm{mg} / \mathrm{L}$ after flowing through the 18.5-km HPDE pipe tail, and resulting BOD $23.0 \mathrm{mg} / \mathrm{L}$ as the effluent to the mangrove forest which is a little high value than standard (BOD less 20 $\mathrm{mg} / \mathrm{L})$. The obtained findings could be the same tendency as reported by [29]. Loopback the former analyzed BOD of the effluent from pond5 were ranged between 0.5 to $25.0 \mathrm{mg} / \mathrm{L}$ which have been satisfied the efficiency since beginning the Royal LERD project, lower values mostly occurring about 2 -m depth and of oxidation ponds 1,2 , and 3 . However, it could be satisfied that BOD $23.0 \mathrm{mg} / \mathrm{L}$ of the treated wastewater or effluent from the last oxidation pond (outflow from pond5) was approximately 9 times as found in the natural mangrove forest (BOD $2.5 \mathrm{mg} / \mathrm{L}$ ) due to rapid organic digestion processing. According to the natural phenomenon in high oxygen content of sea water, the bacterial organic digestion procession was enhanced to lower the values of BOD 2.5, 2.2, and $2.5 \mathrm{mg} / \mathrm{L}$ as indicated in treated wastewater of the natural mangrove forest, mud beach, and seashore. Telling firmly, the DO values in wastewater were found $7.6,6.0,5.9$, and $6.2 \mathrm{mg} / \mathrm{L}$ of pond5 effluent, natural mangrove forest, mud beach, and seashore zones, respectively, on which they might be called as very high existence of DO concentration in water that was the reason why the BOD concentration were high as mentioned before this statement. Also, the research results were found DO in pond5 effluent seemed higher value than DO in treated wastewater in mangrove forest because of high oxygen on the surface wastewater due to phytoplankton photosynthesis and including oxygen diffusion during flowing over the weir crest. It could be pointed out that the former statement were agreed with the research results of [30]. So far, the values of $\mathrm{DO}$ in the natural mangrove forest were trended lower values, perhaps some values of DO could be utilized for bacterial organic digestion processing of plenty litter fall in the natural mangrove forest and moved-in organic matters to the research areas from the rivers of Petchburi, Mae Klong, Thachin, and Chao Phraya.

In similarity, the values of TDS, SS, COD, TKN, nitrate, and phosphate have shown the tendency of better efficiency of the Royal LERD community wastewater treatment system as seen in Table1, but some indicators found uncertainty because of the non-harmony of varying treatment units on surroundings such as soils, contaminants, tree covers, and water components. In case of drastic decreasing of microorganism, the research results in Table1 showed the amount of total coliform bacteria as measured at Klongyang collection pond found the aerobic including some facultative.

Bacteria $7.9 \times 10^{6} \mathrm{CFU} / \mathrm{ml}$. Consequently, there was the anaerobic organic digestion process during flowing through the $18.5-\mathrm{km}$ HPDE pipe that lowering to $3.9 \times 10^{6} \mathrm{CFU} / \mathrm{ml}$ at the 18.5-km HPDE pipe tail. Then after, the drastic decreasing of total coliform bacteria was taken place in wastewater of the natural mangrove forest $\left(1.7 \times 10^{2}\right.$ MPN/100 ml). In addition, the drastic decreases were found in the natural mangrove forest ( $9 \mathrm{MPN} / 100 \mathrm{ml})$, mud beach (11 MPN/100 ml), and seashore ( $<1.8 \mathrm{MPN} / 100 \mathrm{ml}$ ) because of the influence of the high salt content in marine water and due to the death of bacteria which contact air (naturally high content of oxygen) as the limitation of their survival.

Considering the seasonal fluctuation on the analysis of bacteria count that took place on the dates of 10 May 2007 (summer), 15 August 2007 (rainy period), and 12 December 2007 as shown in Table2 and Table3. It could be interpreted that the influence of wastewater treatment in summer period was considered the most drastic decrease on the total coliform bacteria while the middle lowering in winter time, and the least occurring in rainy season. Also, the same tendency was taken place on fecal bacteria. This should be the cause of existing more water for supporting the dilution process in rainy period which is naturally lowered in UV and spectrum rather than in summer and winter time (as measured at the project site) to limit their growth of both the total coliform and fecal bacteria. It could be quite clear understanding that the Royal LERD wastewater treatment system by employing the HPDE pipe with 8 inches in diameter and 18.5 kilometers in length for better rate in decreasing high organic matter concentration by anaerobic process before taking 5-consecutive ponds for Petchaburi municipal wastewater. Closely observation of findings in Table II and Table III pointed out that the higher values of 
both the total coliform and fecal bacteria should be washed off by surface runoff due excess of rainfall in rainy season over the Petchaburi municipal area. Moreover, the extreme existing amount of both the total coliform and fecal bacteria could be the cause of lowering air temperature that possibly making slow processing an anaerobic process as well as cooling on the water surface of the 5-consecutive oxidation ponds.

TABLE I (A): WASTEWATER QUALiTY VALUES As ANALYZED AT FRESH-FOOD MARKETS AND HOUSEHOLDS, MUNICIPAL SEWER, 18.5-HDPE PiPe, 5-Consecutive Ponds, NATURAL Mangrove Forest, Mud Beach, AND SEASHORE OF THE ROYAL LERD

\begin{tabular}{llllll} 
Measuring point & $\begin{array}{l}\text { BOD } \\
(\mathrm{mg} / \mathrm{L})\end{array}$ & $\begin{array}{l}\text { DO } \\
(\mathrm{mg} / \mathrm{L})\end{array}$ & $\begin{array}{l}\text { COD } \\
(\mathrm{mg} / \mathrm{L})\end{array}$ & $\begin{array}{l}\text { Nitrate } \\
(\mathrm{mg} / \mathrm{L})\end{array}$ & $\begin{array}{l}\text { TKN } \\
(\mathrm{mg} / \mathrm{L})\end{array}$ \\
\hline $\begin{array}{l}\text { Fresh Food Market } \\
\text { Sewage Drainage }\end{array}$ & 546.6 & 0.9 & $1,156.0$ & 0.7 & 14.6 \\
$\begin{array}{l}\text { System } \\
\text { Klong Yang }\end{array}$ & 162.7 & 1.0 & 242.9 & 0.2 & 15.3 \\
$\begin{array}{l}\text { Collection Pond } \\
\text { 18.5 km.Pipe End }\end{array}$ & 49.5 & 1.0 & 96.0 & 0.6 & 14.6 \\
5-Treatment Pond & 23.0 & 7.6 & 96.0 & 0.7 & 3.6 \\
Mangrove Forest & 2.5 & 6.0 & 922.0 & 0.1 & 3.8 \\
Mud Beach & 2.2 & 5.9 & 984.0 & 0.1 & 4.0 \\
Seashore & 2.5 & 6.2 & $1,055.0$ & 0.1 & 3.8 \\
\hline \hline
\end{tabular}

TABLE I (B): WASTEWATER Quality VALUES AS ANALyzed AT Fresh-FoOd MARKETS AND HOUSEHOLDS, MuniCIPAL SEWER, 18.5-HDPE Pipe, 5-Consecutive Ponds, Natural Mangrove Forest, Mud Beach, AND SEASHORE OF THE ROYAL LERD

\begin{tabular}{lccccc}
\hline \hline Measuring point & $\begin{array}{l}\mathrm{PO}_{4}^{-} \\
(\mathrm{mg} / \mathrm{L})\end{array}$ & $\begin{array}{l}\mathrm{TDS} \\
(\mathrm{mg} / \mathrm{L})\end{array}$ & $\begin{array}{l}\mathrm{TSS} \\
(\mathrm{mg} / \mathrm{L})\end{array}$ & $\mathrm{pH}$ & $\begin{array}{l}\text { Coliform } \\
\text { Bac. } \\
(\mathrm{mg} / \mathrm{L})\end{array}$ \\
\hline $\begin{array}{l}\text { Fresh Food Market } \\
\text { Sewage Drainage }\end{array}$ & 25.0 & $2,761.9$ & $1,127.0$ & 6.8 & - \\
$\begin{array}{l}\text { System } \\
\text { Klong Yang }\end{array}$ & 4.1 & 462.0 & 100.2 & 7.8 & - \\
Collection Pond & 1.9 & 410.0 & 27.0 & 6.2 & $7.9 \times 10^{6}$ \\
$\begin{array}{l}\text { 18.5 km.Pipe End } \\
\text { 5-Treatment Pond }\end{array}$ & 1.6 & 480.0 & 35.9 & 7.1 & $3.9 \times 10^{6}$ \\
Mangrove Forest & 0.2 & 674.0 & 105.0 & 8.8 & $1.7 \times 10^{2}$ \\
Mud Beach & 0.2 & 32,032 & 138.0 & 8.0 & 9.0 \\
Seashore & 0.22 & 32,784 & 196.0 & 8.0 & $<1.8$ \\
\hline \hline
\end{tabular}

The study on in-pipe organic digestion, there were more less zero of DO concentration (0.00 to $0.08 \mathrm{mg} / \mathrm{L}$ ) through out the closing off the18.5-km HPDE pipe that causing the completion of an anaerobic process (Table IV). Considering in the products of anaerobic organic digestion processes, the more or less changeable indicators of environment in Table4 were found the same patters of $\mathrm{COD}, \mathrm{NH}_{3}, \mathrm{NO}_{2}$, alkalinity, hardness, SS, TDS, temperature, orthophosphate, total coliform, fecal bacterias, and aerobes, but looking evident changes pointed out in BOD and anaerobes. By that evidences, the optimum anaerobic organic digestion process was used for determining the minimum length to decrease the high content of organic matter in wastewater before draining into oxidation ponds for community wastewater treatment as illustrated in Fig. 3. Plotting graph and free hand curving between the distance and BOD in Fig. 3(A) and between anaerobes and the distance in Fig. 3(B) which showed that the minimum distance on W4 (approximately 2,000 meters) in case of the start-up BOD more or less $200 \mathrm{mg} / \mathrm{L}$ in the sewer system and $96 \mathrm{mg} / \mathrm{L}$ (more or less $100 \mathrm{mg} / \mathrm{L}$ ) after pumping such quality into the collection pond.

TABLE II: AMOUNT OF BACTERIA COUNT TOTAL COLIFORM BACTERIA OF PETCHABuri Municipal WASTEWATER ACCORding TO ORganiC Digestion Processes As StaRTED UP From KLONGYANG COLLECTION Pond Through Sedimentation Pond (Pond1) And Another 4 OXIDATION PONDS OF THE ROYAL LERD PROJECT

\begin{tabular}{lccc}
\hline \hline Measuring point & $\begin{array}{c}\text { 10 May 2007 } \\
\text { (Summer) } \\
\text { (MPN/100) }\end{array}$ & $\begin{array}{c}\text { 15 Aug 2007 } \\
\text { (Rainy) } \\
\text { (MPN/100) }\end{array}$ & $\begin{array}{c}12 \text { Dec 2007 } \\
\text { (Winter) } \\
\text { (MPN/100) }\end{array}$ \\
\hline Collection pond & 200,000 & 120,000 & $2,300,000$ \\
18.5 km. Pipe End & 16,000 & 14,000 & 500,000 \\
Pond 1 & 9,200 & 280 & 8,000 \\
Pond 2 & 130 & 130 & 16,000 \\
Pond 3 & 22 & 1,000 & 9,200 \\
Pond 4 & 33 & 140 & 3,500 \\
Pond 5 & 23 & 350 & 28,000 \\
\hline \hline
\end{tabular}

TABLE III: AMOUNT OF BACTERIA COUNT FECAL COLIFORM BACTERIA OF Petchaburi Municipal Wastewater According To Organic Digestion PROCESSES As STARTED Up From KLONGYANG COLlECTION Pond Through Sedimentation Pond (Pond1) And Another 4 OXIDATION PONDS OF THE ROYAL LERD PROJECT

\begin{tabular}{lccc}
\hline \hline Measuring point & $\begin{array}{c}\text { 10 May 2007 } \\
\text { (Summer) } \\
\text { (MPN/100) }\end{array}$ & $\begin{array}{c}\text { 15 Aug 2007 } \\
\text { (Rainy) } \\
\text { (MPN/100) }\end{array}$ & $\begin{array}{c}\text { 12 Dec 2007 } \\
\text { (Winter) } \\
\text { (MPN/100) }\end{array}$ \\
\hline Collection pond & 20,000 & 90,000 & 800,000 \\
18.5 km. Pipe End & 2,700 & 1,300 & 200,000 \\
Pond 1 & 140 & 180 & 5,000 \\
Pond 2 & 11 & 79 & 170 \\
Pond 3 & 7 & 350 & 54 \\
Pond 4 & 11 & 79 & 170 \\
Pond 5 & 2 & 130 & 120 \\
\hline \hline
\end{tabular}

TABLE IV: WASTEWATER QUALITY RANGE AS ANALYED AT KLONGYANG COLLECTION POND, 11 MANHOLdES AND THE SEDIMENTATION POND.

\begin{tabular}{lcc}
\hline \hline Indicators of environment & Unit & Quantity \\
\hline BOD & $\mathrm{mg} / \mathrm{L}$ & $36-96$ \\
$\mathrm{COD}$ & $\mathrm{mg} / \mathrm{L}$ & $112-224$ \\
$\mathrm{DO}$ & $\mathrm{mg} / \mathrm{L}$ & $0.00-0.08$ \\
$\mathrm{NH}_{3}$ & $\mathrm{mg} / \mathrm{L}$ & $2.97-7.37$ \\
$\mathrm{NO}_{2}$ & $\mathrm{mg} / \mathrm{L}$ & $1.281-3.787$ \\
Alkalinity & $\mathrm{mg} / \mathrm{L}$ & $250-298$ \\
Hardness & $\mathrm{mg} / \mathrm{L}$ & $152-172$ \\
Suspended Solid & $\mathrm{mg} / \mathrm{L}$ & $19-56$ \\
Total Dissolved Solid & $\mathrm{mg} / \mathrm{L}$ & $545-576$ \\
Temperature & ${ }^{\circ} \mathrm{C}$ & $30.6-31.2$ \\
EC & $\mu \mathrm{g} / \mathrm{L}$ & $1.281-3.787$ \\
Othophosphate & $\mathrm{mg} / \mathrm{L}$ & $2.026-2.987$ \\
Total Phosphate & $\mathrm{mg} / \mathrm{L}$ & $817-862$ \\
Total Coliform Bacteria & $\mathrm{MPN} / 100 \mathrm{~mL}$ & $350,000-1,600,000$ \\
Fecal Coliform Bacteria & $\mathrm{MPN} / 100 \mathrm{~mL}$ & $110,000-540,000$ \\
Aerobic Bacteria & $\mathrm{CFU} / \mathrm{mL}$ & $1.5 \times 10^{7}-8.6 \times 10^{7}$ \\
Facultative Bacteria & $\mathrm{CFU} / \mathrm{mL}$ & $3.7 \times 10^{7}-36 \times 10^{7}$ \\
Anaerobic Bacteria & $\mathrm{CFU} / \mathrm{mL}$ & $8.3 \times 10^{3}-2,600 \times 10^{3}$ \\
\hline \hline
\end{tabular}




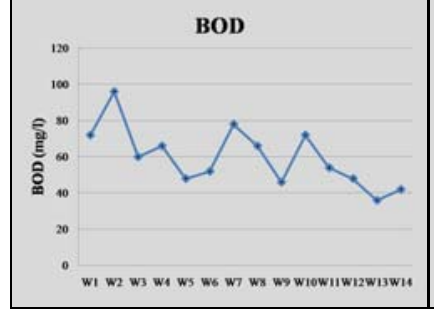

(A)
(B)

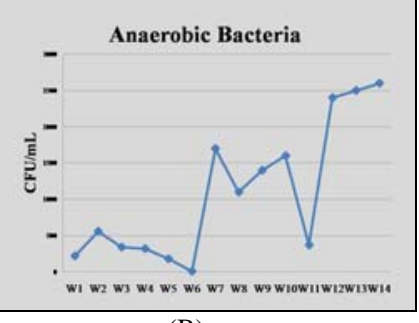

Fig. 3. Graphical determining minimum distance of HPDE pipe for applicable anaerobic organic digestion processing of higher concentrated organic matter to be decreased before draining to oxidation ponds for wastewater treatment of the Royal LERD project site.

\section{CONCLUSION}

Accordance with the existence of high concentrated BOD from various point sources of fresh-food markets, canneries, industrial food factories, and another. Organic matters in wastewater have brought ineffective treatment and needed to use engineering equipment which are more expensive and beyond the ability of the Royal LERD wastewater treatment system. In order to be able to apply the Royal LERD wastewater treatment system, the determination of in-pipe anaerobic organic digestion processing distance was studied on transferring wastewater from Klongyang collection pond through the 18.5-km HPDE pipe with 8 meters in diameters plus sedimentation pond (pond1) and another 4-cosecutive oxidation ponds. The Royal LERD wastewater treatment system found high effectiveness without any argument. In addition, the minimum distance of in-pipe anaerobic organic digestion process was approximated on 2,000 meters for BOD upper $200 \mathrm{mg} / \mathrm{L}$ but it is expected that more value of BOD concentration should be taken with carefulness.

\section{ACKNOWLEDGMENT}

This study was funded by The King's Royally Initiated Leam Phak Bia Environmental Research and Development Project at Laem Phak Bia Sub-distric, Ban-Laem Distric, Petchaburi Province (LERD).

\section{REFERENCES}

[1] LERD, "Economized technology for garbage disposal and wastewater treatment by aquatic plants,” The King's Initiative Laem Phak Bia Environmental Research and Development Project at Laem Phak Bia sub-district, Ban Laem district, Petchburi province, pp. 420, 1999.

[2] O. Jitthaisong, P. Dhanmanonda, and K. Chunkao, "Water quality from mangrove forest: The king's initiative Laem Phak Bia environmental research and development project, Petchaburi Province, Thailand," Modern Applied Science, vol. 6, no. 8, pp. 1-8, 2012.

[3] D. D. Adrian and T. G. Sanders, "Oxygen sag equation for second-order BOD decay,” Water Research, vol. 32, pp. 840-848, 1998.

[4] B. Cazelles, D. Fontvieille, and N. P. Chan, "Self-Purificatiob in a logic ecosystems: A model of dissolved organic carbon and benthic microorganisms dynamies,” Ecological Modelling, vol. 58, pp. 71-117, 1991.

[5] H. Faulkner, V. E. Brown, and A. Green, "Problems of quality designation in diffusely polluted urban streams--the case of Pymme's Brook, north London,” Environmental Pollution, vol. 109, pp. 91-107, 2000.

[6] R. H. S. McColl, "Self-purification of small freshwater stream: phosphate, nitrate, and ammonia,” New Zealand Journal of Marine and Freshwater Research, vol. 8, pp. 375-388, 1974.

[7] Metcalf and Eddy, Inc., Wastewater Engineering: Treatment, Disposal, Reuse, 2nd Ed., McGrow-Hill, New York, USA, pp. 342, 1979.
[8] H. W. Streeter and E. B. Phelps, "A study of the pollution and natural purification of the Ohio River,” U. S. Public Health Service, Bulletin no. vol. 146, pp. 96, 1925.

[9] K. G. Deubigh and G. Raumann, “The thermo-osmosis of gas through a Membrane II,” Experimental Proceeding of Royal Science, vol. 21A, pp. 518-533, 1952.

[10] N. I. Mirmov and I. G. Belyakova, "Heat liberation during vapor condensation in a thermo-siphon,” Journal of Engineering Physics, vol. 43, pp. 970-974, 1982.

[11] P. A. Keddy, Wetland Ecology: Principles and Conservation, (second edition), Cambridge University Press, Cambridge, UK, pp. 497, 2010.

[12] Y. Tanji, R. Sakai, K. Miyanaga, and H. Unnoticed, "Estimation of the self-purification capacity of biofilm formed in domestic sewer pipes," Biochemical Engineering Journal, vol. 31, pp. 96-101, 2006.

[13] S. I. A. Elela, M. M. Came, and M. E. Fawzy, "Biological treatment os saline wastewater using a salt-tererant microorganism,” Desalination, vol. 250, pp. 1-5, 2010.

[14] M. Berhun, "Effects of Ni, Cr, Hg, Cu, Zn, Al on the dissolved oxygen balance of streams," Chemosphere, vol. 59, pp. 207-215, 2005.

[15] S. Cannicci, F. Bartonlini, F. D. Guebas, S. Fratini, C. Litulo, A. Macia E. J. Mrabo, G. P. Lopes, and J. Paula, "Effects of urban wastewater on crab and mollusk assemblages in equatorial and subtropical mangroves of East Affrica,” Estuarine and Self Science, vol. 84, pp. 305-317, 2009.

[16] G. C. Chen, N. F. Y. Tam, Y. S. Wong, and Y. Ye, "Effect of wastewater discharge on greenhouse gas fluxes from mangrove soils," Atmospheric Environment, vol. 45, pp. 1110-1115, 2011.

[17] W. J. Padgett, “A stochastic model for stream pollution,” Mathematical Bioscience, vol. 25, pp. 309-317, 1975.

[18] R. Vagnetti, P. Miana, and B. Pavoni, "Self-purification ability of a resurgence stream,” Chemospherer, vol. 52, pp. 1781-1795, 2003.

[19] M. Wang, J. Zhang, Z. Tu, X. Gao, and W. Wang, "Maintenance of estuarine water quality by mangroves occurs during flood periods; A case study of subtropical mangrove wetland," Marine Pollution Bulletin, vol. 60, pp. 2154-2160, 2010.

[20] K. Chunkao, C. Nimpee, and K. Duangmal, “The King's initiative using water hyacinth to removing heavy metals and plant nutrients from wastewater through Bueng Makkasan in Bangkok Thailand.," Ecological Engineering, vol. 39, pp. 40-52, 2012.

[21] W. J. Padgett, “A stream-pollution model with random Deoxygenation and Reaeration coefficients,” Mathematical Bioscience, vol. 42, pp. 137-148, 1978.

[22] Y. Wu, A. Chung, N. F. Y. Tam, and M. H. Wong, "Constructed mangrove wetland as secondary treatment system for municipal wastewater,” Ecological Engineering, vol. 34, pp. 137-147, 2008.

[23] Q. Yang, N. F. Y. Tam, Y. S. Wong, T. Q. Luanda, W. S. Su, C. Y. LAN, P. K. S. Shin, and S. G. Cheung, "Potential use of mangrove as constructed wetland for municipal sewage treatment in Futian, Shenzhen, China,” Marine Pollution Bulletin, vol. 57, pp. 735-743, 2008.

[24] L. K. Wang, D. Vielkind, and M. H. Wang, "Mathematical model of dissolved oxygen concentration in fresh water," Ecological Modelling, vol. 5, pp. 115-123, 1978.

[25] V. Amaral, G. P. Lopes, and J. Paula, "Effects of vegetation and sewage load on mangrove forest crab condition using experimental mesocosms,” Estuarine Coastal and Self, vol. 84, pp. 300-304, 2009.

[26] APHA, AWWA, and WEF, "Standard methods for the examination of water and wastewater,” 21st Ed.American Public Health Association, Washington, USA, 2005.

[27] B. Tyagi, S. Gakkhar, and D. S. Ghat Ava, "Mathematical Modelling of stream DO-BOD sources," Environmental Modelling and Software, vol. 14, pp. 461-471, 1999.

[28] M. Schaffner, H. P. Bader, and R. Scheidegger, "Model the contribution of point sources and to Thachin river water pollution," Science of the Total Environment, vol. 407, pp. 4902-4915, 2009.

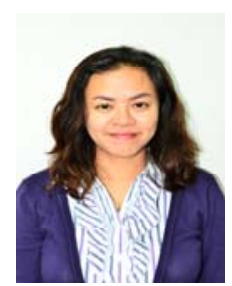

Satreethai Poommai was born in Phitsanulok Province, Thailand. She gained bachelor degree in Agro-Industry and master degree in Natural Resources and Environmental Management from Naresuan University. Now, she is a Ph.D Student of Kasetsart University. She was a scientist of Faculty of Environment, Kasetsart University 12 year ago. 


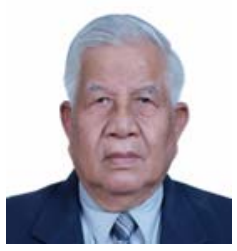

Kasem Chunkao was born in Sukhothai Province, Thailand. About educational background, he gained B.S.F.Hons. Forest Management (Kasetsart University, Thailand, 1963) M.S. Watershed Management (Colorado State University, USA, 1965) Ph.D. Hydrology (University of Washington, USA, 1971) and Ph.D. Environmental Science (Naresuan University, Thailand, 2001) (Honorable Degree). $\mathrm{He}$ was professor in Watershed Management and Environmental Science (since 1982). He has more than 45-year in Environmental Science, Environmental Management, Watershed Management and Forest Hydrology with more than 110 papers on water quality, solid waste, air quality, noise quality, vibration, resources science research, Land Use and Land Cover Change related to Hydrological Processes and Soil Losses, Rainfall and Stream flow, Soil properties and Water Absorption, Sediment flow to Gulf of Thailand. His current jobs are professor of Department of Environmental Science, Faculty of Environment, Kasetsart University and director of the King's Royally Initiated Environmental Research and Development Project.

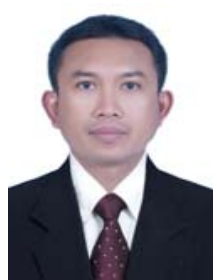

Narouchit Dampin was born on 19 February 1971 in Trang, Thailand. He is now in Dept of Environmental Science, Faculty of Environment, Kasetsart University. He is a Ph.D. (Resources Conservation Ecology) and now working as an lecturer at Kasetsart University.

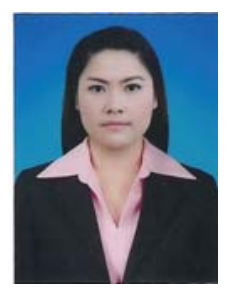

Saowalak Boonmang was born on November 26 , 1984, in Nakhonnayok Province, Thailand. She gained a master degree in Environmental Science and bachelor degree in Education (Agricultural and Environmental Education) from Kasetsart University, Thailand.

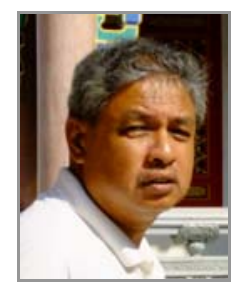

Chatri Nimpee was born on $9^{\text {th }}$ September 1957 in Nonthaburi, Thailand. He got his B.Ed. (General Science). He is now working in the Department of Environmental Science, Faculty Environment, Kasetsart University, Thailand. 